\title{
Long-term genome stability and minimal genotypic and phenotypic alterations in HPV16 E7-, but not E6-, immortalized human uroepithelial cells
}

\author{
Catherine A. Reznikoff, ${ }^{1,2,5,6,9}$ Cassandra Belair, ${ }^{1,5}$ Elena Savelieva, ${ }^{1}$ Yuan Zhai, ${ }^{1}$ Kurt Pfeifer, ${ }^{2}$ \\ Thomas Yeager, ${ }^{1,6}$ Kate J. Thompson,' Sandy DeVries, ${ }^{8}$ Colleen Bindley, ${ }^{3}$ Michael A. Newton, ${ }^{4}$ \\ Gurbax Sekhon, ${ }^{7}$ and Frederic Waldman ${ }^{8}$ \\ Departments of Human Oncology, ${ }_{1}$ Genetics, ${ }^{2}$ Opthamology, ${ }^{3}$ and Biostatistics, ${ }^{4}$ The Environmental Toxicology Center, ${ }^{5}$ \\ The Cell and Molecular Biology Program, ${ }^{6}$ and The Waisman Center, ${ }^{7}$, University of Wisconsin, Madison, Wisconsin \\ 53792 USA; Division of Molecular Cytometry and Department of Laboratory Medicine, ${ }^{8}$ University of California \\ at San Francisco, San Francisco, California 94143 USA
}

Parameters of genome instability and morphological alterations associated with cell transformation were studied in an isogeneic set of clonal human uroepithelial cell (HUC) lines immortalized by the human papilloma virus 16 (HPV16) E6 and/or E7 gene(s). HPV16 E6 binds p53, leading to rapid degradation of p53, whereas $\mathrm{E} 7$ binds and alters $\mathrm{pRb}$ and other proteins. We report that two independent E7-immortalized HUC lines showed minimal phenotypic or genotypic alterations, except that both lines contained amplification of 20q DNA sequences and a greater polyploidization at an early passage. The E7-immortalized HUC line resembled normal HUC lines, except that they failed to senesce. In contrast, the E6-immortalized HUC lines were morphologically altered, contained numerous random chromosome aberrations, and showed unstable evolving karyotypes with passage in culture. No amplified DNA sequences were detected in E6-immortalized HUC lines. Instead, clonal losses of chromosome regions (i.e., $-3 p,-6 q,-9 p$ ), putatively containing tumor suppressor or senescence genes, accompanied the E6-HUC immortalization event. E6-immortalized HUC lines showed transformed phenotypes similar to E6/E7-HUC lines. The difference in genome stability between E6- and E7-immortalized HUC was highly significant statistically (p-value $<10^{-6}$ ). Thus, the HPV16 E7 gene led to HUC immortalization by a pathway that blocked cellular senescence, but did not disrupt genome stability. These results implicate $\mathrm{p} 53$ loss, but not $\mathrm{pRb}$ alteration, in genome destabilization.

[Key Words: HPV16 E6/E7; genome stability; chromosome alterations; DNA amplification; human uroepithelial cells]

Received June 14, 1994; revised version accepted July 27, 1994.

The E6 and E7 transforming genes of certain high risk strains of human papilloma viruses (e.g.,16, 18, 31, 33, and 39) have been identified in many genital carcinomas (zur Hausen 1991). The transforming ability of these HPVs depends on the binding of their E6 and E7 oncoproteins to the products of the TP53 and RB tumor suppressor genes, p53 and pRb, respectively (Munger et al. 1992). E6 binds to p53 resulting in rapid p53 degradation via a ubiquitin protease pathway (Scheffner et al. 1990, 1993; Werness et al. 1990|, whereas E7 binds several cellular proteins including pRb, p107, p130, and cyclin A (Dyson et al. 1989, 1992; Davies et al. 1993; Tommasino

\footnotetext{
${ }^{9}$ Corresponding author.
}

et al. 1993). Both the E6 and E7 genes are integrated and expressed in the majority of cervical cancers (Schwarz et al. 1985; Smotkin and Wettstein 1986; Baker et al. 1987; Wilczynski et al. 1988). Thus, the transforming functions of the E6 and the E7 oncoproteins appear to be synergistic and additive.

Malignant transformation of human urogenital epithelium after infection with high risk HPV in vivo is a multistage process that occurs rarely and usually after a long latent period (zur Hausen 1991). In vitro transformation studies have helped to define some of these steps. For example, it has been shown that immortalization of human epithelial cells by high risk HPV virus occurs in two stages (Shay et al. 1993). The first stage, extension of 
precrisis lifespan is efficient, whereas the second stage, immortalization, rarely occurs. Therefore, it has been hypothesized that immortalization of HPV-transformed cells requires additional genetic alterations, possibly loss of senescence genes (Chen etal. 1993; Shay et al. 1993). Once immortalized, human epithelial cells transformed by the HPV E6/E7 genes are not immediately tumorigenic, but can convert to tumorigenicity after many passages in culture (Hurlin et al 1991; Chen et al. 1993) or after exposure to chemical carcinogens (Li et al. 1992). Such HPV-transformed epithelial cells show morphological alterations, chromosome aberrations, and karyotypic instability.

Our purpose was to determine which transformed phenotypes result from functions of the E6, compared to the E7, oncoprotein. We used human uroepithelial cells (HUC) for our studies. HUC are the epithelium lining the urinary bladder and ureters and the prime target cell type in bladder carcinogenesis. HUC are also a relevant target for HPV infection in vivo (Furihata et al. 1993). In addition, $\mathrm{p} 53$ and $\mathrm{pRb}$ alterations, along with deletions on chromosome 9 , are the most common genetic alterations identified in transitional cell carcinoma (TCC) of the bladder, as recently reviewed (Jones and Droller 1993; Reznikoff et al. 1993). Alterations of pRb and p53 function correlate with late stage invasive TCC (Horowitz et al. 1990; Sidransky et al. 1991; Takahashi et al. 1991), whereas chromosome 9 deletions are associated with low-grade papillary tumors (Olumi et al. 1990; Miyao et al. 1993; Cairns et al. 1993, 1994a; Knowles et al. 1994). Inactivation of TP53 in carcinoma in situ (CIS), an early superficial bladder lesion with a poor prognosis, has been reported (Spruck et al. 1994). The biological significance of $\mathrm{pRb}$ alteration early in HUC tumorigenesis has not been defined. Thus, it would be of great interest to determine the biological significance of HUC that sustained a pRb compared to a p53 alteration early in multistep transformation. We reasoned that the phenotypes of E6-transformed HUC would represent HUC with an early loss of normal p53 function, whereas E7. transformed HUC would represent HUC with an early $\mathrm{RB}$ inactivation.

Immortalization of human epithelial cells by use of HPV16 E6 and E7 together has been accomplished in many laboratories (e.g., Munger et al. 1989;

Hawley-Nelson et al. 1989; Hudson et al. 1990). In contrast, there are few reports of immortalization of human epithelial cells by the E6 (Band et al. 1991; Shay et al. 1993) or E7 (Halbert et al. 1991) gene(s) alone, and there are no reports of immortalization of the same human epithelial cell type with both E6 alone and E7 alone. Nevertheless, we were successful in generating an isogeneic series of HUC immortalized by HPV16 E6 and/or E7 for our studies. We report that HUC lines immortalized by HPV16 E7 were minimally altered both phenotypically and genotypically and showed remarkable longterm genome stability, whereas HUCs immortalized by E6 were phenotypically transformed, showed numerous chromosome alterations, and were karyotypically unstable.

\section{Results}

Generation of an isogeneic set of HPV16 E7 and/or E6 HUC lines

Immortalization of HUC lines by HPV16 genes occurred in two stages, similar to those described previously (Shay et al. 1993). First, cells in all dishes of the three transformation groups (E6, E7, and E6/E7) showed a delayed crisis at passage 5, compared to passage 3 for control HUC (Fig. 1). Thus, the first proposed step of immortalization, precrisis extension of lifespan (M1 stage), was efficient in all groups. Second, after an extended crisis of 2-3 months in which no net gain in cell numbers was apparent, small areas of cells in 2 of 4 E6-, 2 of 4 E7-, and 2 of 2 E6/E7-transformed HUC lines began to proliferate and could be passed. Thus, the second proposed step of immortalization, emergence of an immortal cell line after crisis (M2), was inefficient, but occurred in all groups. The six cell lines used in this study; E7-HUC \#1 and \#2, E6-HUC \#1 and \#2, and E6/E7-HUC \#1 and \#2 were obtained in one experiment with cells from the same ureteral epithelium. Therefore, the set of cell lines is isogeneic in origin.

\section{Characterization of the HPV16 E7- and/or E6- immortalized HUC lines}

Southern blot analysis for HPV16 insertions was done at passages $17-20$ on the six cell lines. Results showed single bands in five lines (even after long exposure of the film), but one line, E6/E7-HUC \#2, showed three bands (Fig. 2). Thus, five of six cell lines had a single integration

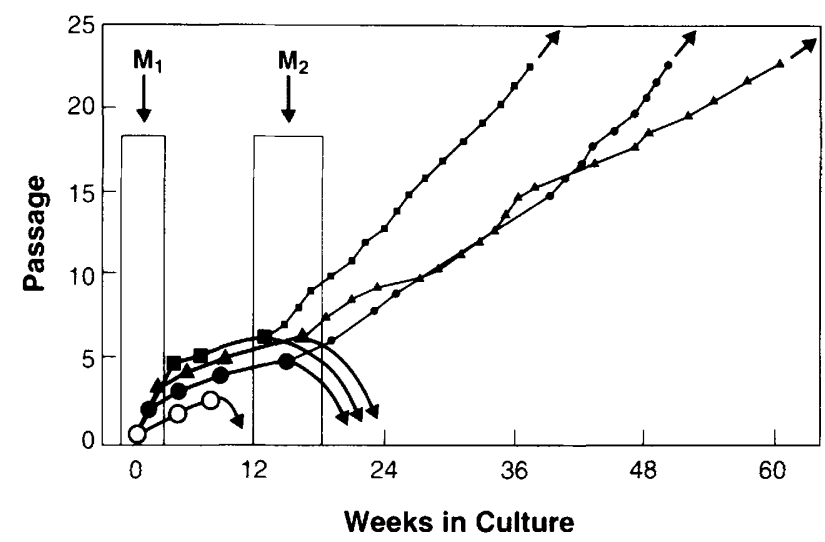

Figure 1. Establishment of HPV16 E6- and/or E7-immortalized HUC lines. The culture history of representative HUC lines transformed by HPV16 E6, E7, or E6/E7 shows that HPV16 HUC E6, E7, and E6/E7 immortalization occurred in two stages (M1 and M2) similar to those reported previously (Shay et al. 1993). All three transformation groups showed a precrisis extension of lifespan (M1 stage) compared with normal HUC $(O)$, followed by a crisis period lasting several months after which most cells died. However, immortal cell lines emerged from two of four E6-HUC (O), two of four E7-HUC ( $\mathbf{\Delta})$, and two of two E6/E7-HUC ( $\mathbf{a}$ groups and have now been proliferating continuously in culture for 20 months and passed $>40$ times. 


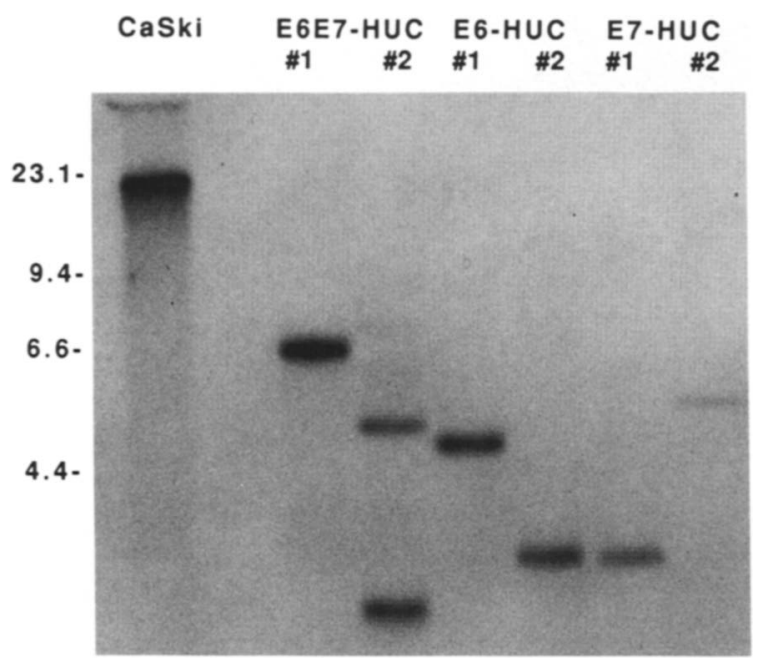

Figure 2. Southern analysis for HPV16 insertions. Southern blot analysis of HPV integration sites in HPV16 E6- and E7immortalized HUC lines was done with HindIII-digested DNA from the six cell lines at passages 17-20. The CaSki cell line containing $\sim 600$ copies of HPV was used as a positive control; this lane was loaded with $0.1 \mu \mathrm{g}$ DNA. All other lanes were loaded with $20 \mu \mathrm{g}$ DNA. Results show single bands in all lanes, except the E6/E7-HUC 2 line. This experiment was reproduced with the same result.

site, and therefore each of these lines derived from a unique clone of transformed cells. These results do not distinguish whether the E6/E7-HUC \#2 line consists of three different clones /representing three transformation events), or one clone with three HPV16 DNA insertion sites. Thus, the E6/E7-HUC \#2 line was not included in the cytogenetic analysis (below). The single band in E6HUC \#2 showed a migration similar on the Southern blot to the single E7-HUC \#1 band. Reverse transcription (RT)-PCR for expression of HPV16 E6 and E7 genes established the independence of these latter two cell lines by their differential expression of $\mathrm{E} 6$ or $\mathrm{E} 7$ and also showed appropriate expression of HPV16 genes in the other four lines (Fig. 3A).

Determination of the status of $\mathrm{p} 53$ protein in the six cell lines was carried out next. Western blot analysis showed that $\mathrm{p} 53$ protein was essentially undetectable in the E6-HUC \#1 and \#2 lines and in the E6/E7-HUC \#1 and \#2 lines, as expected. In contrast, p53 was detectable in the E7-HUC \#1 and \#2 lines, but did not show increased stabilization when compared with an SV40transformed control cell line (Fig. 3B). Immunoperoxidase staining showed the same result (data not shown). Increased stabilization of $\mathrm{p} 53$ is characteristic of most mutations (Lane 1992). Thus, these data do not suggest that p53 alteration occurs in the E7-immortalized HUC lines, although this has been observed in some E7-immortalized human keratinocytes (Demers et al. 1994a).

In summary, each of the five isogeneic HPV16-transformed HUC lines selected for genome analysis in this study, E7-HUC \#1 and \#2, E6-HUC \#1 and \#2, and
E6/E7-HUC \#1, contained a single HPV16 insertion and derived from a unique transformed clone, was therefore independent from the other lines, expressed the appropriate HPV16 E6 and/or E7 gene, and had the expected p53 status based on the functions of E6 and E7.

\section{HPV16 E7-HUC, but not E6 HUC, lines are phenotypically near normal}

Differences were observed among the HPV16 transformed HUC lines. Both the E7-HUC \#1 and \#2 lines, even after 40 passages in culture ( 20 months), remain phenotypically almost indistinguishable by phase contrast microscopy (Fig. 4A) and by transmission electron microscopy (TEM) (Fig. 4C, top) from early passage nonestablished normal HUC (Reznikoff et al. 1987), yet unlike HUC, E7-HUC fail to senesce and are now at passage 40 . In contrast, observation of the E6-HUC \#1 and \#2 lines by phase contrast microscopy (Fig. 4B), as well as by TEM (Fig. 4C, bottom), show a transformed morphology similar to that seen in E6/E7-HUC lines. For

A

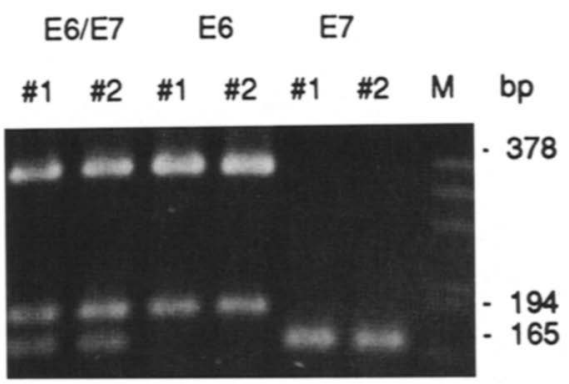

B

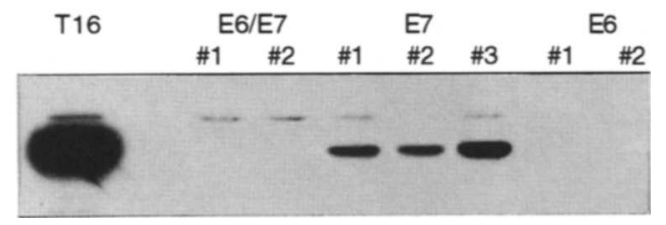

Figure 3. $(A)$ RT-PCR for HPV16 genes expression. The six cell lines used for this study were assessed at P15 for expression of E6 and E7 with total cellular RNA. The appropriate expression of the HPV16 E6 gene products ( 378 and $194 \mathrm{bp}$ ) in the E6-HUC $\# 1$ and \#2 and the E6/E7-HUC \#1 and \#2 lines was noted, as was the expression of the HPV16 E7 gene product (165 bp) in the E7-HUC \#1 and \#2 lines. This experiment was reproduced at later passage with the same result. $(B)$ Western analysis for $\mathrm{p} 53$ protein status. Results of Western blot analysis for p53 protein show undetectable levels of 553 in cells containing the HPV 6 E6 gene. Results also show the expected stabilization of p53 in a cell line transformed by SV40 virus, T16, but not in the E7HUC cell lines. The E7-HUC sample \#3 represents a culture of E7-HUC \#1 exposed to a chemical carcinogen from a separate experiment. 

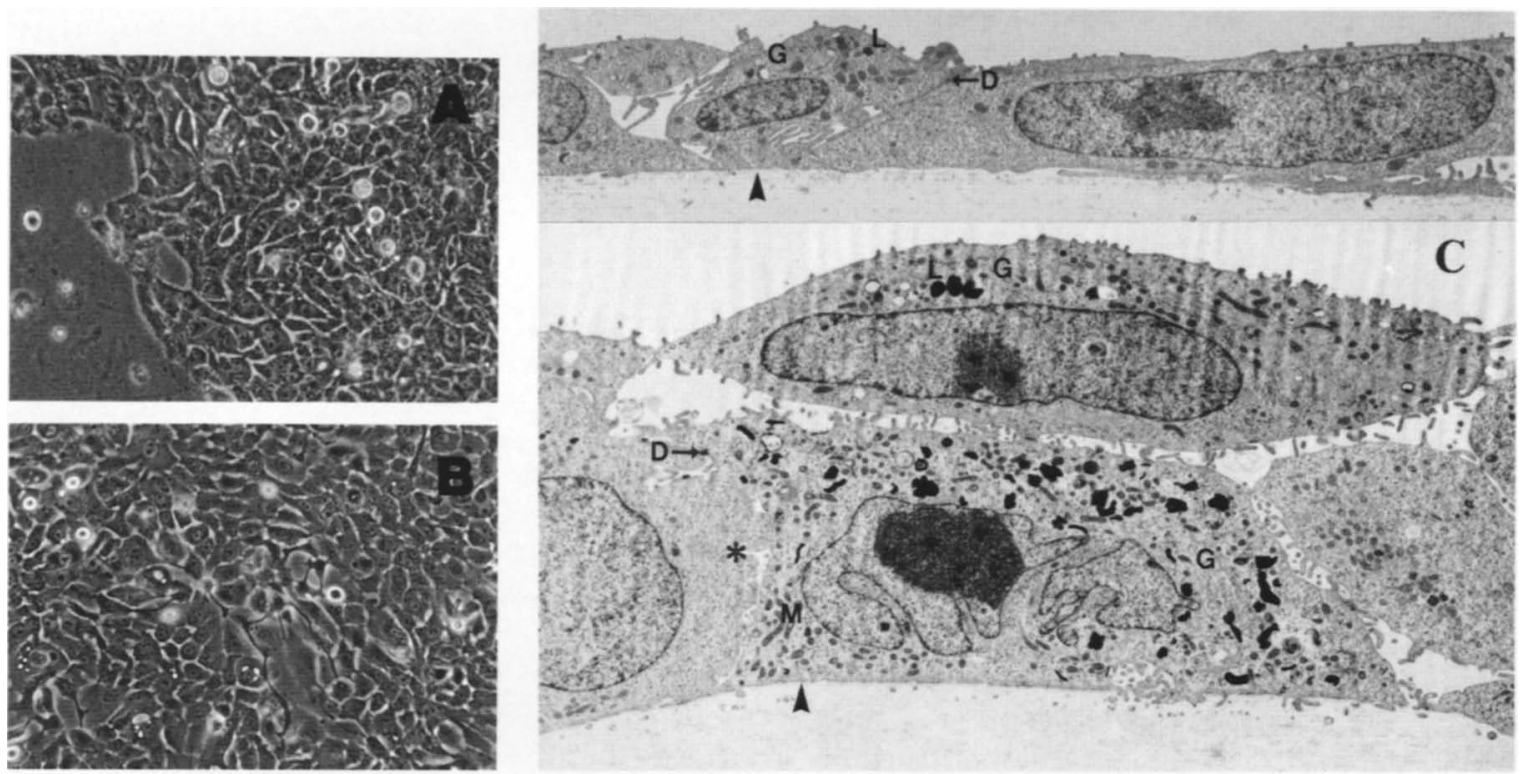

Figure 4. Microscopic analysis of cellular morphology. The phase-contrast morphology of the E7-HUC \#1 line at passage $21(A)$ resembles that of normal HUC at passage 1, showing flat, tightly adherent cells with a typical uroepithelial morphology. In contrast, the E6-HUC \#1 line at passage $23(B)$ shows transformed morphology consisting of irregularly-shaped, more loosely packed cells. Magnification, $200 \times .(C)$ The morphology of the E7-HUC line (top) viewed by TEM showed ultrastructural features seen in normal HUC, including junctional complexes with desmosomes (D) between all cells, apical Golgi (G), basal lamina (arrow), and small regular-shaped surface microvilli. In contrast, the E6-HUC lines (bottom) appear more transformed. They exhibit increased intercellular space, fewer cell-cell junctions, overlapping cells, and irregular-shaped surface microvilli. Cells show more lysosomes (L), mitochondria $(M)$, and intermediate filaments bundles. The cell on the bottom appears to be dying. Magnification of both TEMS, $3500 \times$

example, TEM reveals that E7-HUC lines retain features of normal differentiated HUC in culture (Reznikoff et al. 1987) including tightly adherent cells with junctional complexes such as desmosomes, apical Golgi, basal lamina, and regular shaped surface microvilli covered by a smooth glycocalyx (Fig. 4C, top). Although E6-HUC also show features of normal HUC, there are important differences. Microvilli are more numerous and have irregular club shapes, preconfluent cells pile up and overlap, cells are more loosely packed with increased intercellular space and with fewer desmosomal junctions (Fig. 4C, bottom).

There were also differences in the growth characteristics of E7-HUC and E6-HUC lines. Although both E6HUC and E7-HUC lines grow equally rapidly in culture (doubling approximately once daily, data not shown), E7-HUC lines require a collagen substrate for optimal growth, whereas E6-HUC lines grow equally well on plastic. None of the six HPV16 HUC lines produced tumors after inoculation at passage 25 into athymic nude mice.

Long-term karyotypic stability in E7-HUC, but not in E6-HUC, lines

Cytogenetic analyses were done at early passage to assess karyotypic evidence of genome instability and to determine if clonal chromosome alterations accompanied immortalization. The analysis was repeated after $\sim 10$ passages in culture to assess karyotypic stability. Parameters of genome instability examined included; polyploidization, the numbers and types of structural chromosome anomalies, the stability of the marker chromosomes, and changes in DNA gene balances, that is, losses and duplications. High-level DNA sequence gains (or amplification) were assessed by use of Comparative genomic hybridization (CGH) (below).

Cytogenetic analysis of the E7-HUC \#1 line at passage 15 showed a normal diploid karyotype, with the exception of one clonal (present in every cell) marker chromosome. This marker was designated add(10p)? because it was formed by the addition of apparently new genetic material to the terminus of $10 \mathrm{p}$. This material had the appearance of homogeneous staining regions, and thus its origin could not be deciphered by Giemsa banding (Fig. 5A; Tables 1 and 2). Cytogenetic analysis of the E7-HUC \#2 line at passage 14 also showed normal diploid karyotypes with the exception of a marker chromosome containing cytogenetically unidentifiable material, add(19p)?, present in all cells (Tables 1 and 2). Identification of the additional material on $10 \mathrm{p}$ in the E7HUC \#1 line and on 19p in the E7-HUC \#2 line was done by CGH (below). One additional stable translocation was seen in a minority of cells of the E7-HUC \#2 line (Table 1). The karyotypes of both the E7-HUC \#1 and $\# 2$ lines have remained stable in culture through an additional 10 passages, except for an increase in tetraploidy in the E7-HUC \#1 line (Tables 1 and 2). 

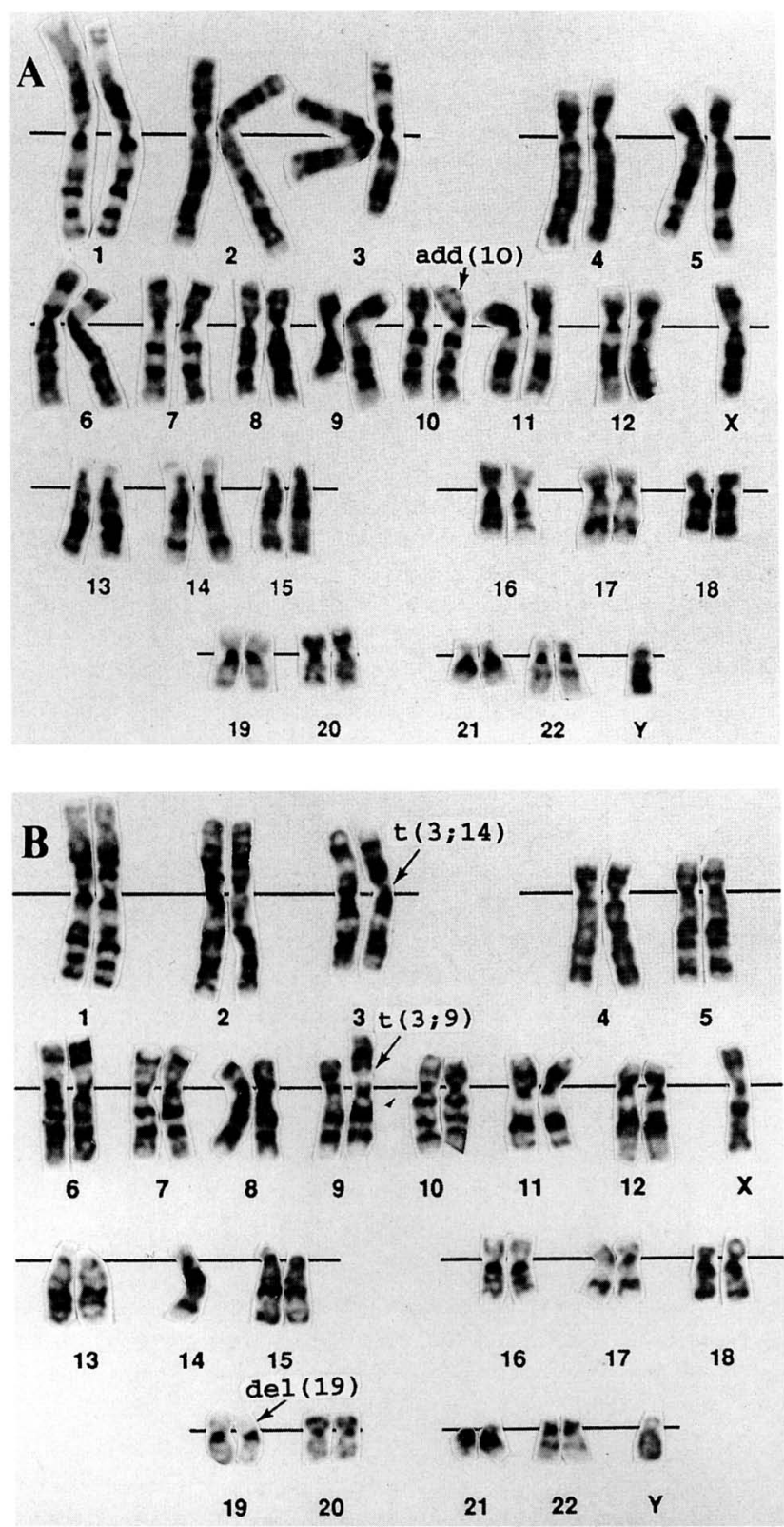

Figure 5. Representative modal karyotypes. $(A \mid$ The modal karyotype of the E7-HUC \#1 line shows normal diploid chromosomes with the exception of cytogenetically unidentifiable material on one 10p chromosome. The E7-HUC \#1 line at passage 15: 46,XY, add(10)(p12.1). Net loss or gain: $-10 \mathrm{p} 12.1 \rightarrow$ pter, add10p12.1. Both changes were clonal. $(B)$ Every E6-HUC \#1 karyotype showed both random and clonal chromosome alterations. E6-HUC \#1 line at passage 20: 45,XY,der $|3| \mathrm{t} \mid 3 ; 14\}$ (p11;q11), der(9)t(3;9)(q21;p13), -14, del(19)(p13.3). Net loss or gain: $-3 \mathrm{p},-9 \mathrm{p} 13 \rightarrow$ pter $,-14 \mathrm{p},-19 \mathrm{p} 13.3 \rightarrow$ pter. The clonal losses are $-3 p$ and $-9 p$ and the random losses are -14 and -19 .

Cytogenetic analysis of early and late passage E6HUC \#1 and \#2 lines revealed a significantly different picture from E7-HUC lines. Although E6-HUC \#1 and \#2 cells remained near diploid in their modal chromo- some numbers, every metaphase cell examined in both lines showed several (average of 4 ) different chromosome aberrations (Table 1). Most of these aberrations were apparently random, as they were present in only a few cells each and not seen again at later passage. However, all E6-HUC \# 1 cells examined contained a clonal derivative chromosome, $\operatorname{der}(3|t| 3 ; 9)$, that resulted in net losses of $3 \mathrm{p}$ and $9 \mathrm{p} 21 \rightarrow$ pter (Fig. 5B). The $\operatorname{der}(3) \mathrm{t} \mid 3 ; 9)$ was unstable with passage in culture, being observed in three forms at passage 8 and two additional forms at passage 23, (L. Savelieva, K. Pfeifer, T. Yeager, C. Belair, and C. Reznikoff, in prep.). The modal karyotype of the E6HUC \#1 line was also unstable and showed evolution when examined at passage 23 with an additional new clonal loss of $4 \mathrm{q}$ and gain of $3 \mathrm{q} 21 \rightarrow \mathrm{qter}$ (Tables 1 and 2 ). The independent E6-HUC \#2 line at passage 15 also had numerous random chromosome anomalies at early passage along with a clonal marker chromosome, $\operatorname{der}(6) t \mid 6 ; 14)$, that caused a net loss of $6 q$ (Tables 1 and 2$)$. The E6-HUC \#2 genome was also unstable as indicated by karyotypic evolution at passage 33 with new clonal marker chromosomes appearing and with an additional clonal net loss of 10p and a gain of $7 \mathrm{p}$ (Tables 1 and 2).

Analysis of the clonal E6/E7-HUC \#1 cell line revealed cytogenetic heterogeneity and instability similar to that observed in E6-HUC \#1 and \#2 lines. E6/E7HUC \#1 cells also contained an unstable clonal derivative marker chromosome, namely der $(10) t \mid 10 ; 20)$, that was present in all cells (Table 1).

Statistical analysis of the data in Table 1 confirmed that significantly fewer structural anomalies occurred in both the E7-HUC \#1 and \#2 lines than in either the E6-HUC \#1 or \#2, or in E6/E7-HUC \#1 lines (p-value $<10^{-6} \mid$, the latter two being similar. This result was obtained by analyzing the two independent replicate samples at the two passages studied. Calculations were based on a Poisson model for the number of anomalies observed. A statistical comparison based on binomial proportions indicated significant differences in polyploidization among the cell lines at early passage. E6/ E7-HUC lines showed more polyploidy than either E6HUC or E7-HUC lines (p-value $<10^{-4}$ ), and E7-HUC lines showed more polyploidy than E6-HUC lines at early passage $(P=0.008)$. Thus, increased polyploidization at early passage was seen in E7-transformed HUC lines, but this was not associated with other parameters of genome instability, such as structural anomalies, clonal marker instability, or karyotypic instability and evolution.

\section{CGH reveals amplified DNA sequences in E7-HUC, not E6-HUC lines}

We used CGH to identify the cytogenetically unidentifiable material on the E7-HUC \#1 and \#2 marker chromosomes, add(10p)? and add(19p)?, and to further check and substantiate the apparent near normal minimally altered stable clonal karyotypes in the E7-HUC cell lines. $\mathrm{CGH}$ is sensitive to deletions spanning $>10 \mathrm{Mb}$ 
Reznikoff et al.

Table 1. Cytogenetic parameters of genome instability in HPV16-transformed HUC

\begin{tabular}{|c|c|c|c|c|c|c|c|c|c|c|c|}
\hline \multirow[b]{2}{*}{ Cell line } & \multirow[b]{2}{*}{$\mathrm{P}$} & \multirow{2}{*}{$\begin{array}{l}\text { Modal } \\
\text { number }\end{array}$} & \multirow{2}{*}{$\begin{array}{l}\text { Percent } \\
\text { polyploid }\end{array}$} & \multicolumn{6}{|c|}{ Structural anomalies } & \multicolumn{2}{|c|}{ Clonal derivative chromosomes } \\
\hline & & & & total & $\mathrm{T}$ & dic & add & iso & del & stable & unstable \\
\hline E7-HUC \# 1 & 15 & 46 & 15 & 1 & - & - & 1 & - & - & $\operatorname{add}(10)$ & - \\
\hline E7-HUC \#1 & 22 & 46 & 33 & 1 & - & - & 1 & - & - & add(10) & - \\
\hline E7-HUC \#2 & 14 & 46 & 14 & 2 & 1 & - & 1 & - & - & add(19) & - \\
\hline E7-HUC \#2 & 27 & 46 & 15 & 2 & 1 & - & 1 & - & - & add(19) & - \\
\hline E6-HUC \#1 & 8 & $44-45$ & 4 & 26 & 6 & 4 & 4 & 1 & 11 & - & $t(3 ; 9)$ \\
\hline E6-HUC \#1 & 23 & $44-45$ & 10 & 21 & 6 & 1 & 6 & - & 8 & - & $t(3 ; 9)$ \\
\hline E6-HUC \#2 & 15 & $43-44$ & 9 & 31 & 10 & 4 & 6 & 5 & 6 & $t(6 ; 14)$ & - \\
\hline E6-HUC \#2 & 33 & $42-43$ & 13 & 14 & 6 & 1 & 4 & 1 & 2 & $\begin{array}{c}\mathrm{t}(6 ; 14), \mathrm{t}(7 ; 22), \mathrm{t}(15 ; 22) \\
\operatorname{add}(15), \operatorname{add}(18)\end{array}$ & - \\
\hline E6/E7-HUC \# 1 & 17 & $43-44$ & 31 & 14 & 10 & 1 & 1 & 1 & 1 & - & $t(10 ; 20)$ \\
\hline
\end{tabular}

(P) Passage; (T) translocation; (dic) dicentric chromosome; (add) additional material of unknown origin (that does not imply any particular mechanism of chromosome alteration); (iso) isochromosome; (del) deletion. (-) None observed. Each unique aberration was counted only once, even if seen in several cells. For each determination, 20 karyotypes were analyzed. Clonal derivative chromosomes were present in every cell. Unstable clonal derivatives were present in several form. For example, at P8 E6-HUC \# $1 \mathrm{t}(3 ; 9)$ was seen as $\operatorname{dic}(3 ; 9)(\mathrm{p} 11 ; \mathrm{p} 21), \mathrm{t}(3 ; ? ; 9)(3 \mathrm{q} 29 \rightarrow 3 \mathrm{p} 11:: ?: ; 9 \mathrm{q} 13 \rightarrow 9 \mathrm{qter})$, and $\operatorname{dic}(3 ; 9)(\mathrm{p} 11 ; \mathrm{p} 13) \operatorname{del}(9)(\mathrm{q} 12 \mathrm{q} 21)$. Ploidy was defined by counting 100 cells for each cell line.

and can detect five- to sevenfold amplifications of small regions, such as amplicons (Kallioniemi et al. 1994).

First, CGH done on later passages of the E7-HUC \#1 (passage 25) line and the E7-HUC \#2 (passage 27) line confirmed the cytogenetic finding of minimal karyotypic alterations and long-term genome stability in both lines (Table 2). CGH indicated a single copy loss of DNA from 10 p12.1 $\rightarrow$ pter in the E7-HUC \#1 (Fig. 6A), which we related to the $10 \mathrm{p}$ marker chromosome formation in this line (shown in Fig. 5A). The E7-HUC \#1 line karyotype was examined again at passage 35 and showed no additional changes (data not shown). No single copy chromosome deletions or duplications were detected in the E7HUC \#2 line. In addition, CGH revealed high-level 20q DNA sequence gains in both the independent E7-HUC
$\# 1$ and \#2 lines (Fig. 6A, A', Fig. 7A, and Table 2). We questioned if this amplification of $20 \mathrm{q}$ sequences may have accompanied E7 immortalization of HUC. To address this possibility, we examined a sibling culture of the E7-HUC \#1 line, E7-HUC 1D, that was separated at passage 6 (the time E7-transformed HUC were emerging from the crisis as shown in Fig. 1), and then cultured independently for 20 passages. Results also showed the 20q DNA sequence gains in E7-HUC \#1D (not shown), indicating that $20 \mathrm{q}$ amplification was present in the E7HUC \#1 cell line at the time of immortalization.

CGH analysis of the E6-HUC \#1 line at passage 23 (Fig. 6B) and the E6-HUC \#2 line at passage 32 showed the clonal chromosome region losses identified by use of cytogenetic analysis and also indicated several addi-

Table 2. Changes in DNA sequence copy number associated with immortalization and passage

\begin{tabular}{|c|c|c|c|c|c|c|}
\hline \multirow[b]{2}{*}{ Cell line } & \multirow[b]{2}{*}{$\mathbf{P}$} & \multicolumn{2}{|c|}{ Technique } & \multirow[b]{2}{*}{ Deletions $^{\mathbf{a}}$} & \multirow[b]{2}{*}{ Gains } & \multirow{2}{*}{$\begin{array}{l}\text { Amplifications } \\
\text { (high-level gains }\end{array}$} \\
\hline & & CHR & $\mathrm{CGH}$ & & & \\
\hline E7-HUC \#1 & 15 & CHR & & $-10 p^{a}$ & $\operatorname{add}(10 p) ?^{a}$ & \\
\hline E7-HUC \#1 & 22 & CHR & & $-10 p$ & add(10p)? & \\
\hline E7-HUC \#1 & 25 & & $\mathrm{CGH}$ & $-10 \mathrm{pl} 2.1 \rightarrow$ pter & - & $20 q+$ \\
\hline E7-HUC \#2 & 14 & CHR & & - & $\operatorname{add}(19 p) ?^{a}$ & \\
\hline E7-HUC \#2 & 25 & CHR & & - & $\operatorname{add}(19 p) ?$ & \\
\hline E7-HUC \#2 & 27 & & $\mathrm{CGH}$ & - & - & $20 \mathrm{q}+$ \\
\hline E6-HUC \#1 & 8 & $\mathrm{CHR}$ & & $-3 p_{t}-9 p 21 \rightarrow$ pter & - & \\
\hline E6-HUC \#1 & 23 & $\mathrm{CHR}$ & & $-3 p,-4,-9$ p $13 \rightarrow$ pter & $+3 q 31 \rightarrow$ qter & \\
\hline E6-HUC \#1 & 23 & & $\mathrm{CGH}$ & $\begin{array}{l}-3 p,-4 q 21 \rightarrow \text { qter } \\
-9 \text { pl } 3 \rightarrow \text { pter }\end{array}$ & $\begin{array}{l}+3 \mathrm{q} 31 \rightarrow \text { qter } \\
+9 \text { cen } \rightarrow \text { q31 }\end{array}$ & (none) \\
\hline E6-HUC \#2 & 15 & CHR & & $-6 q$ & - & \\
\hline E6-HUC \#2 & 33 & $\mathrm{CHR}$ & & $-6 q,-10 p$ & $+7 p$ & \\
\hline E6-HUC \#2 & 32 & & $\mathrm{CGH}$ & $-6 q,-10 p,-Y$ & $+7 p$ & (none) \\
\hline
\end{tabular}

The losses seen at early passage in all four lines were clonal, which indicates a possible role in immortalization. Amplification is scored only for CGH. (P) Passage; (CHR) chromosome analysis; (CGH) comparative genomic hybridization.

${ }^{a}$ Cytogenetic analysis showed changes on 10p indicative of a 10p loss and some gain in E7-HUC \#1 and additional material on 19p in E7-HUC \#2. These were unambiguously identified using CGH as also shown here. 

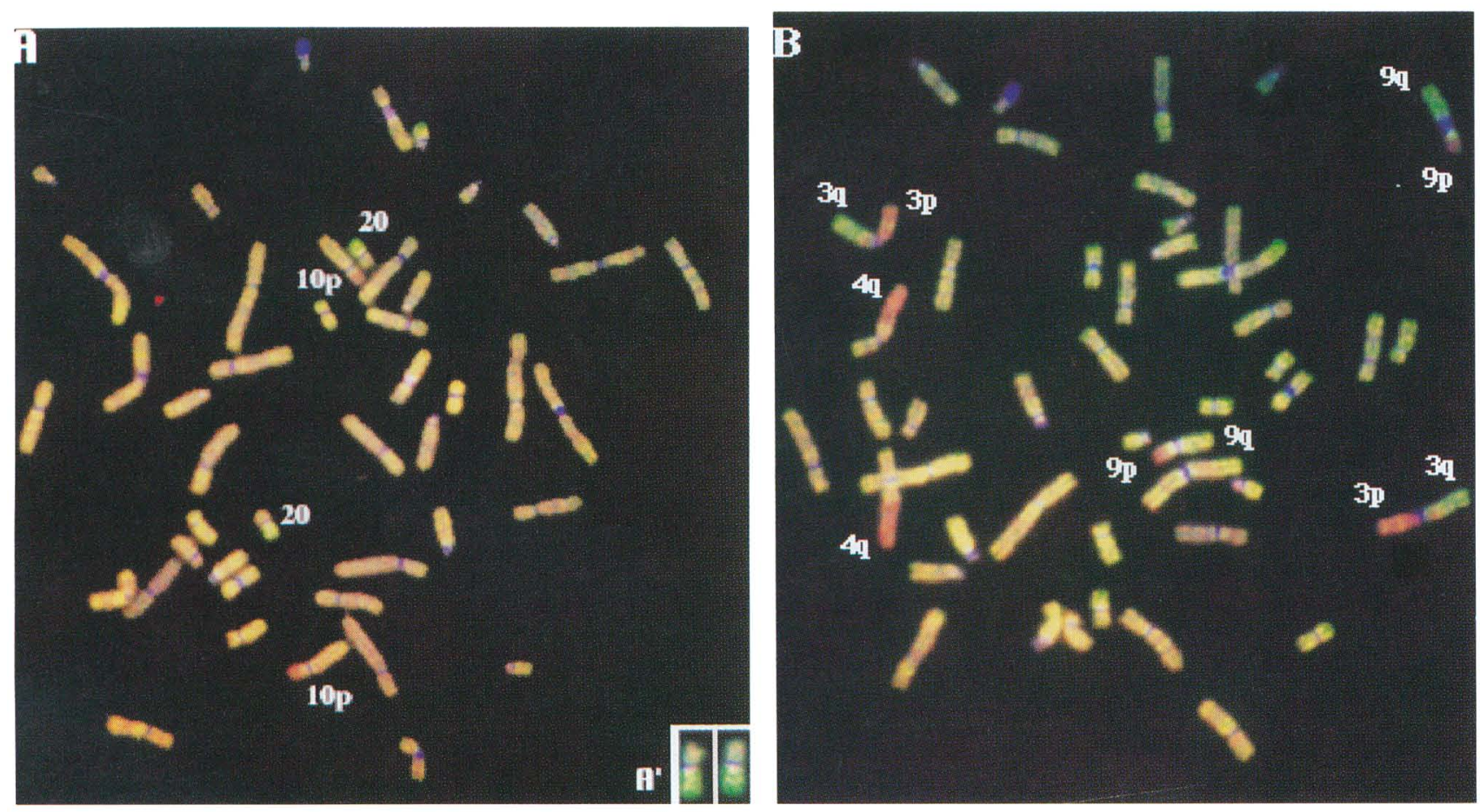

Figure 6. Representative CGH results. Cell line DNA was labeled with fluorescein (green) and normal DNA with Texas red (red). These DNAs were then hybridized to normal metaphase chromosomes. DAPI counterstain appears blue where repetitive DNA has been competed away (centromeres, acrocentric arms, and $\mathrm{Y}$ heterochromatin). DNA sequence losses appear red, and gains appear green. (A) E7-HUC \#1 line showing amplification at $20 \mathrm{q}$ and deletion at $10 \mathrm{p}$. (Inset $A^{\prime}$ ) Sole aberration of $20 \mathrm{q}$ amplification for E7-HUC \#2. (B) The E6-HUC \# 1 line showing losses at 3p, 4q, and 9p, and gains at 3q and 9q. (C) The E6-HUC \#2 line showing losses at $6 \mathrm{q}, 10 \mathrm{p}$, and $\mathrm{Y}$, and gain of $7 \mathrm{p}$. (See Fig. 7 for method used to interpret DNA changes.)

tional changes, thereby unequivocally confirming both the multiple alterations and the genome instability in the E6-HUC lines (Table 2). For example, CGH showed a single-copy deletion of $9 \mathrm{p} 13 \rightarrow$ pter and a single-copy gain of $9 \mathrm{q} 31 \rightarrow \mathrm{qter}$ in the $\mathrm{E} 6-\mathrm{HUC} \# 1$ line at passage 23 (Figs. 6B and 7B). No DNA amplification was detected by CGH in either the E6-HUC \#1 line at passage 23 or the E6-HUC \#2 line at passage 32.

The CGH finding of 20q DNA sequence gains in the E7-HUC \#1 and \#2 lines led us to hypothesize that the cytogenetically unidentifiable material noted on $10 \mathrm{p}$ in the E7-HUC \#1 (Fig. 5A) and on 19p in the E7-HUC \#2 line might consist of amplicons of translocated 20q genes, because both copies of chromosome 20 appeared normal in both cell lines, and no extra normal copies of chromosome $20 \mathrm{q}$ were seen in any of the karyotypes in either cell line. Fluorescence in situ hybridization (FISH) with chromosome 20 painting probes showed a strong signal on 10p in the E7-HUC \#1 line (Fig. 8) and on 19p in the E7-HUC \#2 line (not shown) supporting this possibility.

\section{Discussion}

We generated the first isogeneic set of HPV16 E6- and/or E7-immortalized human epithelial cells. With these cell lines, we were able to study the nature of the genetic events associated with E7 compared with E6 immortalization in the same isogeneic cells. We were also able to assess for the first time long-term genome/karyotype stability in HPV16 E7- compared with E6-transformed human epithelial cells. Our results show that karyotypic instability is associated with a function of HPV16 E6 transformation, but is not necessarily associated with E7 transformation, nor does it necessarily accompany cell immortalization. Furthermore, our results indicate that two types of genetic alterations can accompany immortalization; deletion of putative tumor suppressor/senescence gene regions, which was evident in E6-transformed HUC, and amplification of DNA sequences (on 20q), which was seen in E7-transformed HUC. By extrapolation, these results provide significant new insights into the impact on the tumorigenic process of an early event leading to a p53, compared to a pRb, loss of normal function.

The first important finding is that E6-HUC lines, but not E7-HUC lines, showed significant genome instability, as determined by the presence of multiple chromosome anomalies at early passage after immortalization and by continuing karyotypic instability through longterm (20 months) passage in culture in two independent E6-HUC lines (Tables 1 and 2). The clonal E6/E7-HUC \#1 line also showed chromosome aberrations and marker chromosome instability similar to that seen in 
A
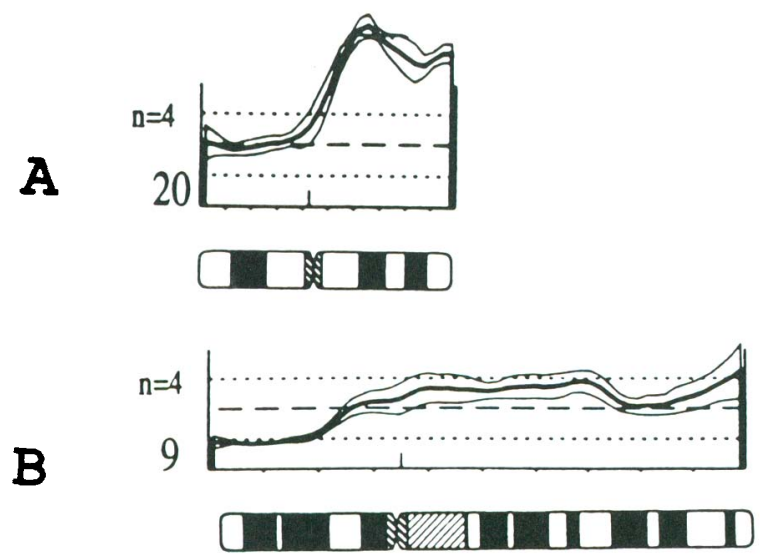

Figure 7. Quantitative interpretation of CGH results. Representative examples of how the green to red fluorescence intensities are quantified using digital image analysis. $(A)$ These data shows that copy number for 20p is unchanged in the E7-HUC \#1 line at passage 25 , but DNA sequences on $20 q$ are amplified, as shown in Fig. 6A. (B) These data suggest a single copy deletion of $9 \mathrm{pl} 3 \rightarrow$ pter and single copy increase (duplication) of $9 \mathrm{qcen} \rightarrow \mathrm{q} 31$ in the E6-HUC \#2 line at passage 23 , as shown in Fig. 6B.

the E6-HUC lines. In contrast, whereas the newly immortal E7-HUC lines showed genome alterations associated with immortalization, their karyotypes remained remarkably stable over long-term culture. This finding associates chromosome instability with the $\mathrm{E} 6$ gene and implicates p53 loss in generating chromosome instability. This possibility is consistent with the predicted biochemical phenotype of $\mathrm{p} 53$ loss of function. It has been proposed that p53 is important in responding to genotoxic damage by signaling cells to arrest at $\mathrm{G}_{1}$ for DNA repair (Kastan et al. 1991; Kuerbitz et al. 1992), and playing a role in the apoptotic response to damage (Lowe et al. 1993a, 1993b). Thus, it has been hypothesized that loss of p53 might lead to genome instability at both the DNA and chromosome levels (Lane et al. 1992; Harris and Hollstein 1993).

Several previous studies associate chromosome alterations with p53 loss. For example, fibroblasts from LiFraumeni patients show chromosome alterations (Bischoff et al. 1990), as do rodent fibroblasts with p53 mutations (Livingstone et al. 1992), and E6-transformed precrisis human fibroblasts (White et al. 1994). These data, along with the current data, strongly implicate $\mathrm{p} 53$ loss in generating a chromosome mutator phenotype. However, a recent study shows that growth arrest by induction of p53 in DNA-damaged keratinocytes is bypassed by HPV16 E7 (Demers et al. 1994b). It will be of interest to determine if other parameters of $\mathrm{p} 53$ function that impact on cell survival after DNA damage, such as apoptosis, are also altered in HPV16 E7 transformed human cells. Clearly, further studies are required to define the mechanism(s) underlying chromosome instability.

It has been hypothesized that HPV immortalization of human cells occurs rarely, because additional genetic changes may be required (Shay et al. 1993; Chen et al. 1993). Our study for the first time identifies specific clonal genetic changes present in all cells at early passage and therefore likely to be associated with immortalization. We found that, against the background of apparently random chromosome aberrations, the newly immortal E6-HUC \#1 and \#2 lines each showed clonal chromosome losses that were associated with the formation of the clonal marker chromosomes. The E6-HUC $\# 1$ line showed losses of $3 \mathrm{p}$ and $9 \mathrm{p} 21 \rightarrow$ pter associated with formation of $\operatorname{der}(3|t| 3 ; 9)$, whereas the E6-HUC \#2 line showed loss of $6 \mathrm{q}$ associated with formation of $\operatorname{der}(6) t(6 ; 14)$. These data associate $3 p$ and/or 9 p21 $\rightarrow$ pter loss in the E6-HUC \#1 line, and 6q loss in the E6-HUC \#2 line with HUC immortalization. Studies are ongoing in our laboratory to determine if this occurs reproducibly in HUC lines. If so, then these findings may indicate a role for genes on these chromosome arms in HUC senescence.

Notably, studies from many laboratories support the hypothesis that chromosome arms $3 p, 6 q$, and $9 p$ contain senescence and/or tumor suppressor genes (for review, see Barrett and Afshari 1994; Seizinger et al. 1991). For example, $3 p$ deletions are common in many cancers. These have been identified in HPV-positive cancers, including nine of nine cervical cancers (for review, see $\mathrm{Mu}$ -

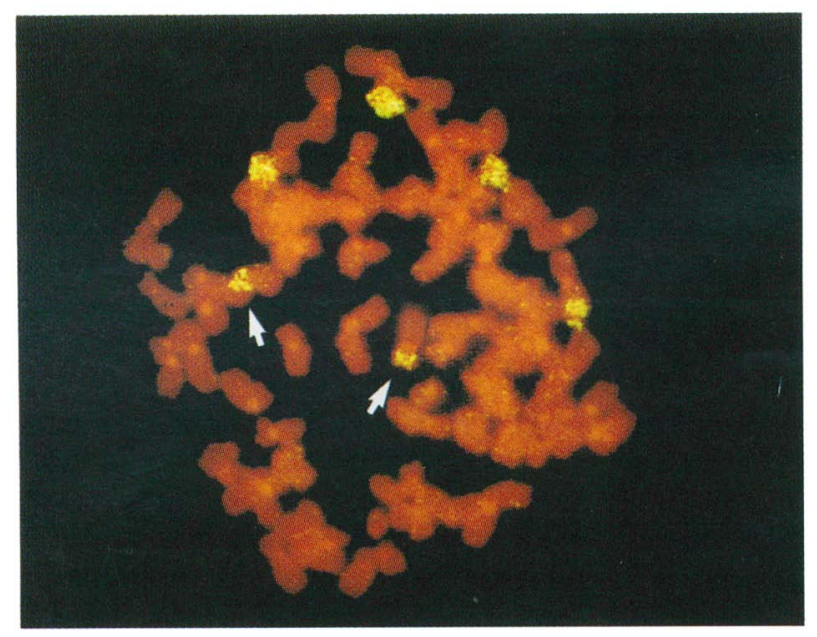

Figure 8. Localization of E7-HUC-amplified 20q DNA sequences. FISH with whole chromosomes 20 paint in a tetraploid of the E7-HUC \#1 line at passage 25 showing six green signals for chromosome 20 sequences. The background chromosome staining is dull red with brighter centromeres. The interpretation is based on G-banding of the same karyotype (not shown). The bright yellow/green doublets represent the four copies of normal chromosome 20 in this tetraploid cell, and the two smaller yellow/green signals (arrows) indicate two 20 sequences localized on two copies of 10p (arrows). Thus, the cytogenetically unidentifiable material on 10 p (Fig. 5A) is from 20. Metaphase E7-HUC \#2 line at passage 27 stained as above showed additional 20 DNA sequences on their clonal add(19p) marker chromosome. Thus, the additional $20 \mathrm{q}$ sequences were on the clonal marker chromosome in the two independent E7-HUC lines. 
nger et al. 1992). We were the first to show 3p loss in urothelial cancers (Klingelhutz et al. 1991, Newton et al. 1994). We also showed that 3p loss is associated with SV40 immortalization of HUC lines (Kao et al. 1992). Loss of $3 p$ was subsequently identified in $\sim 20 \%$ of clinical bladder cancers using CGH (A. Kalliioniemi, G. Citron, S. Devries, P.C. Kerschmann, P. Carroll, O. -P. Kallionieme, and F. Waldman, in prep.). Thus, these data indicate that $3 \mathrm{p}$ may play a role in a subset of human bladder cancers. A role for $6 \mathrm{q}$ loss in human cell immortalization and tumorigenic transformation has also been documented. For example, introduction of chromosome 6 induces senescence in SV40-transformed fibroblasts (Sandhu et al. 1994) and controls tumorigenicity in human melanoma cell lines (Trent et al. 1990). Chromosome $6 \mathrm{q}$ and $3 \mathrm{p}$ losses are also found in cultured human TCC (Brown et al. 1994), but these are not reported frequently. In contrast, chromosome 9 loss (usually the whole chromosome) is the most common genetic alteration identified in TCC (Tsai et al. 1990; Knowles et al. 1994). It occurs in $>50 \%$ of low grade TCC (Cairns et al. 1994a), often as the only change (for review, see Sandberg and Berger 1994). The deletions on chromosome $9 \mathrm{p}$ have been centered at 9p21 (Cairns et al. 1993; Miyao et al. 1993; Ruppert et al. 1993; Stadler et al. 1994). In our molecular analysis of early passage the E6-HUC \#1 line shows loss of heterozygosity in the same $9 \mathrm{p} 21$ region ( $T$. Yeager, W. Stadfern, D. Sidranskin, L. Savelieva, K. Pfeifer, C. Belair, C. Parker, E. Messing, and C. Reznikoff, in prep.).

A candidate 9p21 tumor suppressor gene, multiple tumor suppressor 1 (MTS1), was recently proposed (Kamb et al. 1994). However, the rates of MTS1 mutations in primary tumors with $9 \mathrm{p}$ loss is significantly less than is observed in cell lines derived from these same tumor types (Cairns et al. 1994b). Thus, loss of MTSI may contribute to establishment of tumor cells in culture, and may in some cases give tumor cells a growth advantage in vivo, but may not be the primary target of 9p21-22 allelic loss in these same tumor types. These observations raise the possibility that the same genes frequently lost in association with adaptation of cells to culture may not be those most frequently lost in tumor progression in vivo.

It is notable that the E6-HUC \#1 and \#2 lines showed losses of different putative tumor suppressor or cellular senescence gene regions. In view of a recent report (Ryan et al. 1994) questioning the existence of immortality complementation groups (Pereira-Smith et al. 1988), it will be of great interest to determine if somatic cell hybrids between the E6-HUC \#1 and \#2 lines are mortal.

Clonal genetic alterations also accompanied E7 immortalization. Both independent E7-HUC lines showed amplification of $20 \mathrm{q}$ sequences translocated to their clonal marker chromosomes, $10 p+$ and $19 p+$. To check if these 20q DNA sequence gains occurred specifically in association with the immortalization event, we examined a sibling line of E7-HUC \#1, E7-HUC \#1D, that was separated immediately after the crisis and cultured independently for 20 passages.
E7-HUC \#1D also showed 20q DNA amplification. $20 \mathrm{q}$ amplification was the only genetic alteration detected in E7-HUC \#2. Amplification of genes on 20q occurs in breast, bladder, and colon cancers /Kallioniemi et al. 1994; F.M. Waldman, pers. comm.). Our finding of amplification of $20 \mathrm{q}$ genes in association with HUC immortalization is therefore likely to be significant, as it suggests that amplification or overexpression of some gene on $20 \mathrm{q}$ may have played a role in immortalization. The notion that dominant acting oncogenes may play a role in blocking programmed cell death is relatively new. One such candidate gene is $\mathrm{Bcl}-\mathrm{x}$ (located on 20q), which functions as a dominant regulator of cell death (Boise et al. 1993; Schneider et al. 1994). The presence of amplified DNA in the E7-HUC lines does not preclude the possibility that loss of recessive genes also have played a role in E7-HUC immortalization. The E7-HUC \#1 line showed a $10 \mathrm{p}$ deletion, and inapparent losses could also have occurred in the E7-HUC \#2 line (possibly on 19p). We are using somatic cell hybridization to test the dominance versus recessiveness of immortality in the E7HUC lines, as well as in the E6-HUC lines.

It has been proposed that loss of $\mathrm{p} 53$ potentiates gene amplification in response to genotoxic agents (Livingstone et al. 1992; Yin et al. 1992). Although the current studies demonstrate for the first time apparently spontaneous gene amplification associated with E7 immortalization, they do not disallow a greater potential for gene amplification in E6-transformed cells given appropriate selective pressure. Our results are in agreement with earlier studies indicating that E7-transformed cells show more polyploidization than E6-transformed cells (Takashi and Yasumoto. 1991; White et al. 1994). These new data add to previous analyses by showing that over time, E6-transformed cells also show polyploidization comparable to E7 (Table 1). We identified genome alterations at early passages in the E7-HUC \#1 and \#2 lines, but we do not interpret this to indicate that E7 transformation leads to genome instability, as the clonal karyotypes of both the E7-HUC \#1 and \#2 lines subsequently remained stable and unaltered for many passages in vitro as discussed above. Therefore, neither the alterations resulting from $\mathrm{E} 7$ binding to $\mathrm{pRb}$ or other cellular proteins, nor the subsequent changes associated with the immortalization event bestowed genome instability on the E7HUC lines. This lack of genome alterations is reflected in the minimal phenotypic alterations observed in E7HUC lines.

These studies have profound implications for understanding the significance of the order in which genetic events occur in the pathogenesis of human carcinoma. By extrapolation, our results suggest a model of HUC tumorigenesis in which an early loss of p53 function leads to genome instability with more rapid tumor progression (Fig. 9), whereas an early loss of pRb modulates proliferation, allowing spontaneous mutations that block cellular senescence to occur, but does not per se destabilize the genome. Thus, progression would depend on additional genetic alterations that cause genome instability, such as p53 mutation. This model is consistent 
Reznikoff et al.

Figure 9. An in vitro model of HPV16 HUC multistep transformation.

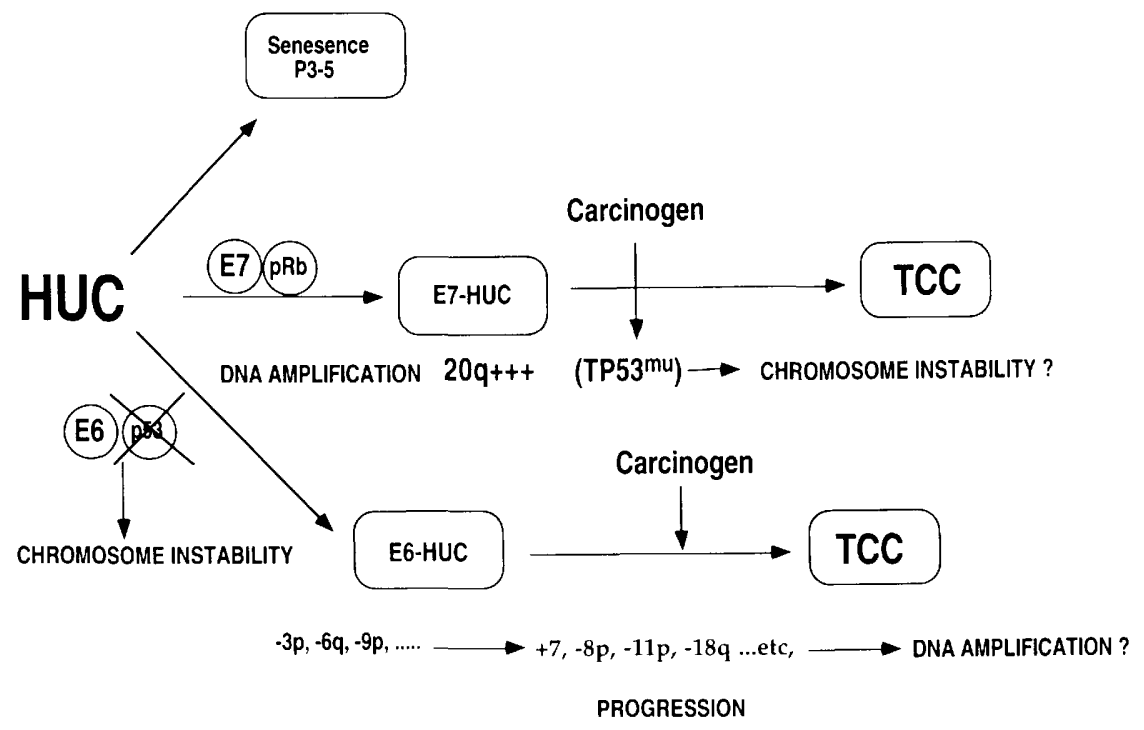

with a molecular model of clinical TCC recently proposed by Peter Jones (Spruck et al. 1994). The validity of the model we have developed is strongly supported by the excellent concordance between the genetic alterations observed in this in vitro model of HUC transformation and those observed in authentic clinical TCC (Table 3).

\section{Materials and methods}

\section{HUC establishment and cell culture methods}

Primary explant cultures of HUC were initiated from normal ureteral uroepithelium on collagen-coated $100-\mathrm{mm}$ plastic dishes (Corning) and grown in 1\% FBS-F12+, a supplemented Ham's F12 medium (GIBCO) with fetal bovine serum (FBS) added (Sigma) exactly as described previously (Reznikoff et al. 1987). The one piece of normal ureteral mucosa used for these experiments was stripped from a piece of ureter left over from kidney transplantation surgery. The kidney donor was a healthy 44 year old male with no history of cancer. The medium on all cultures was changed three times weekly. Cells were dispersed for subculture with $0.1 \%$ EDTA in Hanks' balanced salt solution (Reznikoff et al. 1987). Cell numbers and percent viability were determined with hemocytometers on singly dispersed cell samples stained for $5 \mathrm{~min}$ with $0.1 \%$ trypan blue stain (Sigma).
Cultures were kept in a humidified incubator at $37^{\circ} \mathrm{C}$ in $5 \%$ $\mathrm{CO}_{2}$.

\section{Transformation of HUC with HPV16 genes}

Primary (10-day-old) HUC were dispersed and seeded at $5 \times 10^{5}$ viable cells/100-mm collagen-coated dish. After $48 \mathrm{hr}$, HUC were infected with $10^{5}$ infectious units/dish of HPV16 E6/E7, E6, or E7 genes carried on amphotropic retroviral vectors, LXSN, LXSN16E7, LXSN16E6, or LXSN16E6E7 /a kind gift of Dr. D. Galloway, Fred Hutchinson Cancer Research Center, Seattle, WA). Virus was prepared and titered as described previously (Halbert et al. 1991). Neomycin at 200 units per ml (GIBCO) was added at $48 \mathrm{hr}$ to select for transformed cells. Cells in all dishes were given regular changes of medium and passed when preconfluent. Two control dishes were uninfected and senesced as expected at passage 3 .

\section{TEM and tumorigenicity assessments}

Representative cultures of the E7-HUC \#1 and E6-HUC \#1 lines were used for TEM when cultures were newly confluent. TEM was done exactly as described previously (Reznikoff et al. 1987). To test for tumorigenic transformation, cells from the six HPV16-transformed lines were each inoculated subcutaneously into four sites of 3- to 4-week-old female athymic mice (BALB

Table 3. Concordance between genetic alterations in bladder cancer and HPV-HUCs

\begin{tabular}{|c|c|c|c|c|c|c|c|}
\hline \multirow{2}{*}{$\frac{\text { Sample }}{\text { Bladder cancer }^{a}}$} & \multirow{2}{*}{$\begin{array}{l}\text { Transformation } \\
\text { stage }\end{array}$} & \multicolumn{3}{|c|}{ Losses } & \multicolumn{3}{|c|}{ Gains/amplifications } \\
\hline & & $\begin{array}{r}3 \mathrm{p}, 4,6,8 \mathrm{p}, 9 \\
9\end{array}$ & $11 p$ & $13 q, 17 p, 18 q, Y$ & $11 p, 1 q, 3 q, 5 p$ & $, 7,8 \mathrm{q}$ & $13 q, 20 q$ \\
\hline HPV-HUCs ${ }^{b}$ & $\begin{array}{l}\text { late } \\
\text { early } \\
\text { later }\end{array}$ & $3 \mathrm{p}, \quad 6 \mathrm{p}, \quad 8 \mathrm{p}, \quad 9 \mathrm{p}$ & & $13 q, 17 p, 18 q$ & $3 q$ & $\begin{array}{l}7 \\
7\end{array}$ & $20 q$ \\
\hline
\end{tabular}

a Data taken from Sandberg and Berger (1994); Knowles et al. (1994); F.M. Waldman (pers. comm.).

bShown here are all clonal changes seen at early passages in E7-HUC \#1 and \#2 and in E6-UC \# 1 and \#2. The later alterations include changes seen at later passages in $>50 \%$ of the same cell lines (data from Table 2 ). 
nude/nude: Harlan Sprague-Dawley, Madison, Wisconsin) with $2 \times 10^{6}$ cells per site (Kao et al. 1992).

\section{Southern blot, RT-PCR, and Western blot analyses}

High-molecular-weight DNA and total cellular RNA were isolated from preconfluent cultures by use of the guanidine isothiocyanate (Sigma) method (Kao et al. 1992). DNA and RNA concentrations were quantified spectrophotometrically, and 20 $\mu \mathrm{g}$ was loaded on each lane, except the E7-HUC \#2 lane, which was underloaded. Southern blot analysis to detect HPV16 insertions was done on a Hybond-N membrane (Amersham) with HindIII-digested DNAs as described previously (Kao et al. 1992). After transfer, the membrane was probed with the $0.8-\mathrm{kb}$ BamHI-HindIII fragment from p1321 (a gift from Dr. P. Howley, Harvard Medical School. Boston, MA) that contains the HPV16 E6/E7 genes labeled by random priming with $\left[\alpha^{-32} \mathrm{P}\right] \mathrm{dCTP}$. DNA from the HPV16 positive CaSki cell line was used as a positive control.

RT-PCR was used to check for appropriate expression of the E6 and/or E7 genes in HPV16-transformed HUC. For RT-PCR, the GeneAmp RNA PCR kit (Perkin Elmer) was used. Briefly, reverse transcription with random hexamers was done on $1 \mu \mathrm{g}$ of total cellular RNA with 2.5 units/ $\mu$ l M-MoLV RT /GIBCOBRL). Multiplex PCR was done with 30 cycles (each $1 \mathrm{~min}$ at $95^{\circ} \mathrm{C}$ and $30 \mathrm{sec}$ at $60^{\circ} \mathrm{C}$ ) and then 1 cycle of $7 \mathrm{~min}$ at $60^{\circ} \mathrm{C}$ with both the $\mathrm{E} 6$ and $\mathrm{E} 7$ primers together. The final concentration of $\mathrm{MgCl}_{2}$ was $2 \mathrm{~mm}$. The E6 primers were 5'end, AATGTTTCAGGACCCACAGG and 3' end, TGGAAATCTTTGCTTTTTGTC, which yield two products (378 and $194 \mathrm{bp}$ ) resulting from alternately spliced mRNAs (Band et al. 1991). The E7 primers were $5^{\prime}$ end, ATGACAGCTCAGAGGAGGAG and $3^{\prime}$ end, TTAACAGGTCTTCCAAAGTAC, which yield a single 165-bp product (Munger et al. 1989). Taq DNA polymerase (Boehringer Mannheim) was used at $5 \mathrm{U} / 100 \mu \mathrm{l}$. The PCR products were analyzed on $3 \%$ NuSieve agarose gels (FMC) and stained with ethidium bromide. No products were obtained without RT in the reaction tubes.

Western blot analysis was done by use of a pantropic antibody that recognizes all forms of p53 (AB2, Oncogene Science). The Pierce HRP-conjugated goat anti-mouse IgG heavy and light chain was the secondary antibody. This was detected by the enhanced chemiluminescence (ECL) method. Cell lysates were prepared as described previously (Kao et al. 1993). Lanes were loaded with $100 \mu \mathrm{g}$ of protein. An SV40-transformed HUC line, $\mathrm{T} 16$, was used as a positive control for stabilized p53.

\section{Chromosome analysis}

Karyotypic analysis was done on trypsin-banded Leishmanstained metaphase chromosomes by use of a modification of the Seabright method (Seabright 1971). To arrest cells in metaphase, colcemid (GIBCO) at a final concentration of $0.2 \mathrm{ng} / \mathrm{ml}$ was added to the medium of proliferating cells and left on for $2-3 \mathrm{hr}$. Cells were then removed from the dishes with EDTA as above, spun down at $700 \mathrm{rpm}$ for $7 \mathrm{~min}$, and resuspended in $8 \mathrm{ml}$ of 75 $\mathrm{mM} \mathrm{KCl}$ for $20 \mathrm{~min}$ at $37^{\circ} \mathrm{C}$. A $3: 1 \mathrm{methanol} /$ acetic acid fixative was added $(0.5 \mathrm{ml})$ to the hypotonic solution. Cells were spun down as before and exposed to four changes of the fixative. The cell suspension was then dropped onto glass slides (prepared by heating at $90-95^{\circ} \mathrm{C}$ for $15 \mathrm{~min}$ ). Banding was done by exposing cells to $0.1 \mathrm{ml}$ of $0.5 \%$ trypsin (GIBCO) in $50 \mathrm{ml}$ of isotonic solution ( $\mathrm{pH} 7.0$ ), for $4 \mathrm{~min}$. Finally, cells were stained for $2 \mathrm{~min}$ with Leishman stain (Sigma) prepared by diluting the stock (dissolved in methanol) in Gurr buffer, $\mathrm{pH}$ 6.2. The final rinse was done in tap water. For each analysis, a minimum of 20 meta- phase spreads were karyotyped. Determination of modal numbers was based on counts of chromosomes in 50 cells.

\section{Comparative genomic hybridization}

Hybridization of differentially labeled tumor and normal DNA to normal metaphase chromosomes was performed essentially as described previously (Kallioniemi et al. 1992, 1994). Normal mononuclear metaphase preparations were denatured at $70^{\circ} \mathrm{C}$ for $2 \mathrm{~min}$ in denaturation solution $(70 \%$ formamide, $2 \times \mathrm{SSC}$, $\mathrm{pH} 7)$ and dehydrated in graduated ethanols. Slides were then treated with proteinase $\mathrm{K}(0.1 \mu \mathrm{g} / \mathrm{ml}$ in $20 \mathrm{~mm}$ Tris- $\mathrm{HCl}, 2 \mathrm{~mm}$ $\mathrm{CaCl}$ at $\mathrm{pH} 7.5)$ and again dehydrated. DNA was isolated from HUC lines and from peripheral blood from a normal healthy male donor according to standard procedures. Cell line DNA was labeled by nick translation with fluorescein 12-dUTP, and normal DNA was labeled with Texas red-5-dUTP. All hybridizations were validated by a repeat experiment with cell-line DNA labeled with Texas red-dUTP and normal DNA labeled with fluorescein-dUTP. Labeled tumor and normal DNAs 1200 $\mathrm{ng})$ were ethanol precipitated with $10 \mu \mathrm{g}$ of unlabeled Cot-1 DNA, dissolved into $10 \mu \mathrm{l}$ of hybridization buffer $\{50 \%$ formamide, $10 \%$ dextran sulfate, $2 \times \mathrm{SSC}$ at $\mathrm{pH} 7$ ), denatured at $70^{\circ} \mathrm{C}$ for $5 \mathrm{~min}$, and applied onto the metaphase slides. The hybridization was done at $37^{\circ} \mathrm{C}$ for 2 days. After hybridization, slides were washed three times in wash buffer $\$ 50 \%$ formamide, $2 \times$ $\mathrm{SSC}$ at $\mathrm{pH} 7 \mathrm{l}$ and once in $2 \times \mathrm{SSC}$ at $45^{\circ} \mathrm{C}$ for $10 \mathrm{~min}$ each, twice in $\mathrm{PN}$ buffer $(0.1 \% \mathrm{NP}-40$ in PBS at $\mathrm{pH} 8)$ at room temperature, and once in distilled water. Slides were then counterstained with 4,6-diamidino-2-phenylindole (DAPI) in antifade solution. CGH hybridization results were quantified by use of a QUIPS digital image analysis system based on a Zeiss fluorescence microscope, a Photometrics cooled CCD camera, and a Sun workstation. Three-color images (DAPI, fluorescein, Texas red) were collected from 5 metaphases for each sample. Green and red fluorescence intensities from pter to qter and the ratio of green to red intensity were calculated for each chromosome in the metaphase spread. In each metaphase cell, the absolute fluorescence intensities were normalized so that the average green to red ratio of all chromosomes in the metaphase was 1.0. The final results were expressed as the mean green to red ratio profiles +1 SD determined from two to three metaphase cells (four observations per chromosomel. Only images that showed uniform high-intensity fluorescence in both green and red color, no background spots, and where the two chromatids showed the same changes were evaluated.

\section{FISH}

FISH to locate the amplified 20q DNA sequences was done on trypsin-banded Leishman-stained metaphase chromosomes by use of techniques described previously (Kao et al. 1993). Briefly, we used whole-chromosome paint (wcp) 20-green with FITClabeled probes (Oncor, Gaithersburg, MD) according to the vendor's protocol, which included one-step amplification.

\section{Acknowledgments}

We gratefully acknowledge the critical review of the manuscript by our friend, Professor Howard M. Temin of the McArdle Laboratory for Cancer Research, before his recent death of cancer. We dedicate this study to his memory with great affection. C.A.R. thanks Dr. William Reznikoff for thoughtful discussions. We thank Dr. Chinghai Kao for his help in the beginning phases of this project and Mr. Kowit Chong for technical assis- 
tance. This research was supported by National Institutes of Health (NIH) RO1-CA-29525, P01-CA-519870, and a gift from the Haertle Family to C.A.R. The CGH studies were supported by grant R01-47537 to F.W. Thomas Yeager was supported by an $\mathrm{NIH}$ training grant T32E507015 to the Cell and Molecular Biology Program at the University of Wisconsin.

The publication costs of this article were defrayed in part by payment of page charges. This article must therefore be hereby marked "advertisement" in accordance with 18 USC section 1734 solely to indicate this fact.

\section{References}

Baker, C.C., W.C. Phelps, V. Lindgren, M.J. Braun, M.A. Gondas, and P.M. Howley. 1987. Structural and translational analysis of human papilloma virus type 16 sequences in cervical carcinoma cell lines. J. Virol. 61: 962-971.

Band, V., J.A. DeCaprio, L. Delmolino, V. Kulesa, and R. Sager. 1991. Loss of $\mathrm{p} 53$ protein in human papillomavirus type 16 E6-immortalized human mammary epithelial cells. J. Virol. 65: $6671-6676$.

Barrett J.C. and C.A. Afshari. 1994. Cellular senescence and the cell cycle. In The cell cycle: Regulators, targets, and clinical applications (ed. V. Hu), pp. 79-89. Plenum Press, New York.

Bischoff, F.Z., S.O. Yim, S. Pathak, G. Grant, M.J. Siciliano, B.C. Giovanella, L.C. Strong, and M.A. Tainsky. 1990. Spontaneous abnormalities in normal fibroblasts from patients with Li-Fraumeni cancer syndrome: Aneuploidy and immortalization. Cancer Res. 50: 7979-7984.

Boise, L.H., M. Gonzales-Garcia, C.E. Postema, L. Ding, T. Lindsten, L.A. Turka, X. Mao, G. Nunez, and C.B. Thompson. 1993. Bcl-x, a Bcl-2-related gene that functions as a dominant regulator of apoptotic cell death. Cell 74: 597-608.

Brown, J.L., R. Lukeis, Z. Palividis, J. Wass, D. Raghavan, and P.J. Russell. 1994. Karyotypic analysis of a heterogeneous human transitional cell carcinoma of the bladder. Cancer. Genet. Cytogenet. 72: 116-125.

Cairns, P., M.E. Shaw, and M.A. Knowles. 1993. Preliminary mapping of the deleted region of chromosome 9 in bladder cancer. Cancer Res. 53: 1230-1232.

-1994a. Initiation of bladder cancer may involve deletion of a tumor-suppressor gene on chromosome 9. Oncogene 8: 83-86.

Cairns, P., L. Mao, A. Merlo, D.J. Lee, D. Schwab, U.Y. Eby, K. Tokino, P. van der Riet, J.E. Blaugrund, and D. Sidransky. 1994b. Rates of p16 (MTS1) mutations in primary tumors with 9p loss. Science 265: 415-417.

Chen, T.-M., G. Pecoraro, and V. Defendi. 1993. Genetic analysis of in vitro progression of human papilloma virus-transfected human cervical cells. Cancer Res. 53: 1167-1171.

Davies, R., R. Hicks, T. Crook, J. Morris, and K. Bousden. 1993. Human papilloma vinus type 16 E7 associated with a histone $\mathrm{Hl}$ kinase and with p107 through sequences necessary for transformation. J. Virol. 67: 2521-2528.

Demers, G.W., C.L. Halbert, and D Galloway. 1994a. Elevated wild-type p53 protein levels in human epithelial cell lines immortalized by the human papillomavirus types 16 E7 gene. Virology 198: 169-174.

Demers, G.W., S.A. Foster, C.L. Halbert, and D.A. Galloway. 1994b. Growth arrest by induction of p53 in DNA damaged keratinocytes is bypassed by human papillomavirus $16 \mathrm{E} 7$. Proc. Natl. Acad. Sci. 91: 4382-4386.

Dyson, N., P.M. Howley, K. Munger, and E. Harlow. 1989. The human papilloma virus $16 \mathrm{E} 7$ oncoprotein is able to bind to the retinoblastoma gene product. Science 243: 934-937.

Dyson, N., P. Guida, K. Munger, and E. Harlow. 1992. Homologous sequences in adenovirus E1A and human papilloma virus E7 proteins mediate interaction with the same set of cellular proteins. J. Virol. 66: 6893-6902.

Furihata, M., K. Inoue, Y. Ohtsuki, H. Hashimoto, N. Terao, and Y. Fugita. 1993. High-risk human papillomavirus infections and overexpression of $\mathrm{p} 53$ protein as prognostic indicators in transitional cell carcinoma of the urinary bladder. Cancer Res. 53: 4823-4827.

Halbert, C.L., G.W. Demers, and D.A. Galloway. 1991. The E7 gene of human papillomavirus type 16 is sufficient for immortalization of human epithelial cells. I. Virol. 65: 473478.

Harris, C.C. and M. Hollstein. 1993. Clinical implications of the p53

tumor-suppressor gene. N. Engl. I. Med. 329: 1318-1327.

Hashida, T. and S. Yasumoto. Induction of chromosome abnormalities in mouse and human epidermal keratinocytes by the human papillomavirus type 16 E7 oncogene. 1991. I. Gen. Virol. 72: 1569-1577.

Hawley-Nelson, P., K.H. Vousden, N.L. Hubbert, D.R. Lowy, and J.T. Schiller. 1989. HPV16 E6 and E7 proteins cooperate to immortalize human foreskin keratinocytes. $E M B O /$. 8: 3905-3910.

Hollstein, M., D. Sidransky, B. Vogelstein, and C. Harris. 1991. p53 mutations in human cancers. Science 253: 49-53.

Horowitz, J.M., S.-H. Park, E. Bogenmann, J.-C. Cheng, D.W. Yandell, F.J. Kaye, J.D. Minna, T.P. Dryja, and R.A. Weinberg. 1990. Frequent inactivation of the retinoblastoma antioncogene is restricted to a subset of human tumor cells. Proc. Natl. Acad. Sci. 87: 2775-2779.

Hudson, J.B., M.A. Bedell, D.J. McCance, and L.A. Laimins. 1990. Immortalization and altered differentiation of human keratinocytes in vitro by the $\mathrm{E} 6$ and $\mathrm{E} 7$ open reading frames of human papillomavirus type 18. I Virol. 64: 519-526.

Hurlin, P.J., P. Kaur, P.P. Smith, N. Perez-Reyes, R.A. Blanton, and J.K. McDougall. 1991. Progression of human papilloma virus type 18-immortalized human keratinocytes to a malignant phenotype. Proc. Natl. Acad. Sci. 88: 570-574.

Jones, P.A. and M.J. Droller. 1993. Pathways of development and progression in bladder cancer: New correlations between clinical observations and molecular mechanisms. Sem. Urol. 11: 177-192.

Kallioniemi, A., O.-P. Kallioniemi, D. Sudar, D. Rutovitz, J.W. Gray, F.M. Waldman, and D. Pinkel. 1992. Comparative genomic hybridization for molecular genetic analysis of solid tumors. Science 258: 818-821.

Kallioniemi, A., O.-P. Kallioniemi, J. Piper, M. Tanner, T. Stokke, L. Chen, H.S. Smith, D. Pinkel, J.W. Gray, and F.M. Waldman. 1994. Detection and mapping of amplified DNA sequences in breast cancer by comparative genomic hybridization. Proc. Natl. Acad. Sci. 91: 2156-2160.

Kamb, A., N.A. Gruis, J. Weaver-Feldhaus, Q. Liu, K. Harshman, S.V. Tavtigian, E. Stockert, R.S. Day III, B.E. Johnson, and M.H. Skolnick. 1994. A cell cycle regulator potentially involved in genesis of many tumor types. Science 264: 436440.

Kao, C., S.-Q. Wu, M. Bhatthacharya, L.F. Meisner, and C.A. Reznikoff. 1992. Losses of 3p, 11p, and 13q in EJ/ras-Transformable simian virus

40-immortalized human uroepithelial cells. Genes Chrom. Cancer 4: 158-168.

Kao, C., S.Q. Wu, S. DeVries, W. Reznikoff, F.M. Waldman, and C.A. Reznikoff. 1993. Carcinogen-induced amplification of SV40 DNA inserted at 9q12-21.1 associated with chromo- 
some breakage, deletions, and translocations in human uroepithelial cell transformation in vitro. Genes Chromo. Cancer 8: 155-166.

Kastan, M.B., O. Onyekwere, D. Sidransky, B. Vogelstein, and R.W. Craig. 1991. Participation of p53 protein in the cellular response to DNA damage. Cancer Res. 51: 6304-6311.

Klingelhutz, A.J., S.-Q. Wu, E.A. Bookland, and C.A. Reznikoff. 1991. Allelic 3p deletions in high-grade carcinomas after transformation in vitro of human uroepithelial cells. Genes Chrom. Cancer 3: 346-357.

Knowles, M.A., P.A. Elder, M. Williamson, J.P. Cairns, M.E. Shaw, and M.G. Law. 1994. Allelotype of human bladder cancer. Cancer Res. 54: 531-538.

Kuerbitz, S.J., B.S. Plunkett, W.V. Walsh, and M.B. Kastan. 1992. Wild-type p53 is a cell cycle checkpoint determinant following irradiation. Proc. Natl. Acad. Sci. 89: 7491-7495.

Lane, D.P. 1992. p53, guardian of the genome. Nature 358: 1516.

Li, S.-L., M.S. Kim, H.M. Cherrick, J. Doniger, and N.-H. Park. 1992. Sequential combined tumorigenic effect of HPV16 and chemical carcinogens. Carcinogenesis 13: 1981-1987.

Livingstone, L.R., A. White, J. Sprouse, E. Livanos, T. Jacks, and T. Tlsty. 1992. Altered cell cycle arrest and gene amplification potential accompany loss of wild-type p53. Cell 70: 923-935.

Lowe, S.W., H.E. Ruley, T. Jacks, and D.E. Housman. 1993a. p53-Dependent apoptosis modulates the cytotoxicity of anticancer agents. Cell 74: 957-967.

Lowe, S.W., E.M. Schmitt, S.W. Smith, B.A. Osborne, and T. Jacks. 1993b. p53 is required for radiation-induced apoptosis in mouse thymocytes. Nature 362: 847-852.

Miyao, N., Y.C. Tsai, S.P. Lerner, A.F. Olumi, C.H. Spruck III, M. Gonzalez-Zulueta, P.W. Nichols, D.G. Skinner, and P.A. Jones. 1993. Role of chromosome 9 in human bladder cancer. Cancer Res. 53: $4066-4070$.

Munger, K., W.C. Phelps, V. Bubb, P.M. Howley, and R. Schlegel. 1989. The E6 and E7 genes of the human papillomavirus type 16 together are necessary and sufficient for transformation of primary human keratinocytes. I. Virol. 63: 44174421.

Munger, K., M. Scheffner, J.M. Huibregtse, and P.M. Howley. 1992. Interactions of HPV E6 and E7 oncoproteins with tumor suppressor gene products. Cancer Surv. 12: 197-212.

Newton, M.A., S.-Q. Wu, and C.A. Reznikoff. 1994. Assessing the significance of chromosome loss data: Where are the suppressor genes for bladder cancer? Stat. Med. 13: 839-858.

Olumi, A.F., Y.C. Tsai, P.W. Nichols, D.G. Skinner, D.R. Cain, L.I. Bender, and P.A. Jones. 1990. Allelic loss of chromosome $17 \mathrm{p}$ distinguishes high grade from low grade transitional cell carcinomas of the bladder. Cancer Res. 50: 7081-7083.

Pereira-Smith, O.M. and J.R. Smith. 1988. Genetic analysis of indefinite division in human cells: Identification of four complementation groups. Proc. Natl. Acad. Sci. 85: 60426046.

Reznikoff, C.A., L.J. Loretz, D.M. Pesciotta, T.D. Oberley, and M.M. Ignjatovic. 1987. Growth kinetics and differentiation in vitro of normal human uroepithelial cells on collagen gel substrates in defined medium. J. Cell. Physiol. 131: 285-301.

Reznikoff, C.A., C. Kao, E.M. Messing, M. Newton, and S. Swaminathan. 1993. A molecular genetic model of human bladder carcinogenesis. Sem. Cancer Biol. 4: 143-152.

Ruppert, J.M., K. Tokino, and D. Sidransky, 1993. Evidence for two bladder cancer suppressor loci on human chromosome 9. Cancer Res. 53: 5093-5095.

Ryan, P.A., V.M. Maher, and J.J. McCormick. 1994. Failure of infinite lifespan human cells from different immortality complementation groups to yield finite lifespan hybrids. $/$. Cell. Physiol., in press.

Sandberg, A.A. and C.S. Berger. 1994. Review of chromosome studies in urological tumors. Cytogenetics and molecular genetics of bladder cancer. I. Urol. 151: 545-560.

Sandhu, A.K., K. Hubbard, G.P. Kaur, K.K. Tha, H.L. Ozer, and R.S. Athwal. 1994. Senescence of immortal human fibroblasts by the introduction of normal human chromosome 9 . Proc. Natl. Acad. Sci. 91: 5498-5502.

Scheffner, M., B.A. Werness, J.M. Huibregtse, A.J. Levine, and P.M. Howley. 1990. The E6 oncoprotein encoded by human papillomavirus types 16 and 18 promotes the degradation of p53. Cell 63: 1129-1136.

Scheffner, M., J.M. Huibregtse, R.D. Vierstra, and P.M. Howley. 1993. The HPV-16 E6 and E6-AP complex functions as a ubiquitin-protein ligase in the ubiquitination of p53. Cell 75: 495-505.

Schneider, J.W., W. Gu, L. Zhu, V. Mahdavi, and B. Nadal-Ginard. 1994. Reversal of terminal differentiation mediated by pl07 in RB - / - muscle cells. Science 264: 1467-1471.

Schwarz, E., U.K. Freese, L. Gissman, W. Mayer, B. Roggenbuck, A. Stremlau, and H. zur Hausen. 1985. Structure and transcription of human papilloma virus sequences in cervical carcinoma cells. Nature 314: 111-114.

Seabright, M. 1971. Rapid binding technique for human Chromosomes. Lancel 11: 971-972.

Seizinger, B.R., H.P. Klinger, C. Junien, Y. Nakamura, M. LeBeau, W. Cavenee, B. Emanuel, B. Ponder, S. Naylor, F. Mitelman, D. Louis, A. Menon, I. Newsham, J. Decker, M. Kaelbling, I. Henry, and A. Deimling. 1991. Report of the committee on chromosome and gene loss in human neoplasia. Cytogenet. Cell. Genet. 58: 1080-1096.

Shay, J.W., W.E. Wright, D. Brasiskyte, and B.A. Van Der Haegen. 1993. E6 of human papillomavirus type 16 can overcome the $\mathrm{Ml}$ stage of immortalization in human mammary epithelial cells but not in human fibroblasts. Oncogene 8: $1407-1413$.

Sidransky, D., A. Von Eschenbach, Y.C. Tsai, P. Jones, I. Summerhayes, F. Marshall, M. Paul, P. Green, S.R. Hamilton, P. Frost, and B. Vogelstein. 1991. Identification of p53 gene mutations in bladder cancers and urine samples. Science 252: 706-709.

Smotkin, D. and F.O. Wetstein. 1986. Transcription of human papilloma virus type 16 early genes in a cervical cancer and a cancer derived cell line and identification of the $\mathrm{E} 7$ protein. Proc. Natl. Acad. Sci. 83: 4680-4684.

Spruck, C.H. III, P.F. Ohneseit, M. Gonzalez-Zulueta, D. Esrig, N. Miyao, Y.C. Tsai, S.P. Lerner, Ch. Schmutte, A.S Yang, R. Cote, L. Dubeau, P.W. Nichols, G.G. Hermann, K. Steven, T. Horn, D.G. Skinner, and P.A. Jones. 1994. Two molecular pathways to transitional cell carcinoma of the bladder. Cancer Res. 54: 784-788.

Stadler, W.M., J. Sherman, S.K. Bohlander, D. Roulston, M. Dreyling, D. Rukstalis, and O.I. Olopade. 1994. Homozygous deletions within chromosomal bands 9p21-22 in bladder cancer. Cancer Res, 54: 2060-2063.

Takahashi, R., T. Hashimoto, H.-J. Xu, S.-X. Hu, T. Matsui, T. Miki, H. Bigo-Marshall, S.A. Aaronson, and W.F. Benedict. 1991. The retinoblastoma gene functions as a growth and tumor suppressor in human bladder carcinoma cells. Proc. Natl. Acad. Sci. 88: 5257-5261.

Tommasino, M., J.P. Adamczewski, F. Carlotti, C.F. Barth, R. Manetti, M. Contorni, F. Cavalieri, T. Hunt, and L. Crawford. 1993. HPV16 E7 protein associated with a protein kinase p33CDK2 and cyclin A. Oncogene 8: 195-202.

Trent, J.M., E.J. Stanbridge, H.L. McBride, E.U. Meese, G. Casey, 


\section{Reznikoff et al.}

D.E. Araujo, C.M. Witkowski, and R.B. Nagle. 1990. Tumorigenicity in human melanoma cell lines controlled by introduction of human chromosome 6. Science 247: 568-571.

Tsai, Y.C., P.W. Nichols, A.L. Hiti, Z. Williams, G.D. Skinner, and P.A. Jones. 1990. Allelic losses of chromosomes 9, 11, and 17 in human bladder cancer. Cancer Res. 50: 44-47.

Werness, B.A., A.J. Levine, and P.M. Howley. 1990. Association of human papilloma virus types 16 and $18 \mathrm{E} 6$ proteins with p53. Science 248: 76-79.

White, A.E., E.M. Livanos, and T.D. Tlsty. 1994. Differential disruption of genomic integrity and cell cycle regulation in normal human fibroblasts by the HPV oncoproteins. Genes \& Dev. 8: 666-677.

Wilczynski, S.P., L. Pearlman, and J. Walker. 1988. Identification of HPV16 early genes retained in cervical carcinomas. Virology 166: 624-627.

Yin, Y., M.A. Tainsky, F.Z. Bischoff, L.C. Strong, and G.M. Wahl. 1992. Wild-type p53 restores cell cycle control and inhibits gene amplification in cells with mutant p53 alleles. Cell 70: 937-948.

zur Hausen, H. 1991. Human papilloma viruses in the pathogenesis of analgenital cancer. Virology 184: 9-13. 


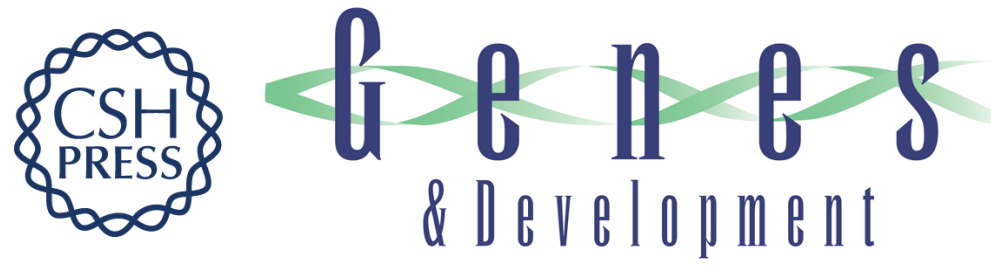

\section{Long-term genome stability and minimal genotypic and phenotypic alterations in HPV16 E7-, but not E6-, immortalized human uroepithelial cells.}

C A Reznikoff, C Belair, E Savelieva, et al.

Genes Dev. 1994, 8:

Access the most recent version at doi:10.1101/gad.8.18.2227

References This article cites 69 articles, 38 of which can be accessed free at:

http://genesdev.cshlp.org/content/8/18/2227.full.html\#ref-list-1

License

Email Alerting

Service

Receive free email alerts when new articles cite this article - sign up in the box at the top right corner of the article or click here.

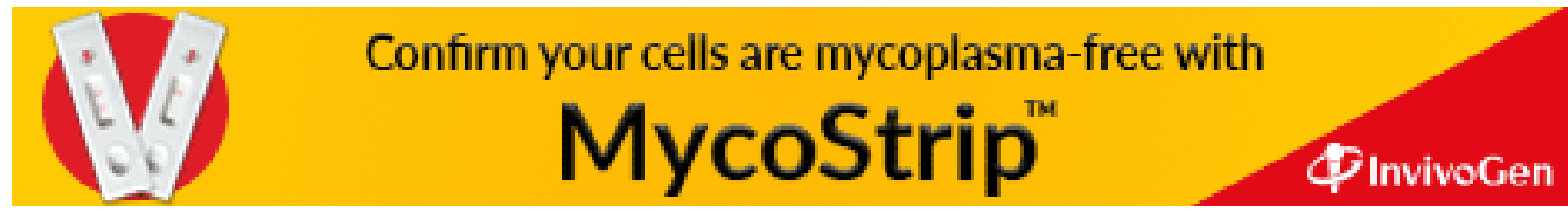

